\title{
SOIL MICROBIAL BIOMASS AND ACTIVITY IN WETLANDS LOCATED IN PRESERVED AND DISTURBED ENVIRONMENTS IN THE CERRADO BIOME
}

\author{
BIOMASSA E ATIVIDADE MICROBIANA DO SOLO EM VEREDAS SITUADAS EM \\ AMBIENTES CONSERVADOS E ANTROPIZADOS NO BIOMA CERRADO
}

\section{Ricardo Fernandes de SOUSA ${ }^{1}$; Eliana Paula Fernandes BRASIL ${ }^{2}$; Cícero Célio de FIGUEIREDO ${ }^{3}$; Wilson Mozena LEANDRO ${ }^{2}$}

1. Agronomist, Professor, Instituto Federal de Educação, Ciência e Tecnologia de Goiás - IFG, Goiânia, GO, Brazil. rifego@yahoo.com.br; 2. Professor, PhD, Escola de Agronomia - EA, Universidade Federal de Goiás - UFG, Goiânia, GO, Brazil; 3. Professor, PhD, Faculdade de Agronomia e Medicina Veterinária - FAV, Universidade de Brasília - UnB, Brasília, DF, Brazil.

\begin{abstract}
The veredas (a type of wetlands) are wet ecosystems usually associated with the presence of hydromorphic soils, which often occur in the vicinity of springs and watercourses of the Cerrado region in Brazil. This study aimed to assess microbiological and biochemical soil properties in wetlands (veredas) located in preserved and disturbed environments (in farming and grazing areas) in the Cerrado biome. Soil samples were collected at depths of 0-10 $\mathrm{cm}$ and 10-20 $\mathrm{cm}$, along reference lines arranged according to their position in the landscape, in the upper, middle and lower positions of one of the slopes. The total soil organic carbon, microbial biomass carbon and nitrogen $\left(\mathrm{C}_{\text {mic }}\right.$ and $\left.\mathrm{N}_{\text {mic }}\right)$, microbial biomass $\mathrm{C}: \mathrm{N}$ ratio, microbial quotient, basal respiration, metabolic quotient and fluorescein diacetate (FDA) hydrolytic activities in soil (as total soil heterotrophic enzymatic activity) were determined. The soils of veredas adjacent to agricultural and livestock environments showed changes in their biological properties compared to preserved ecosystems. Increased microbial biomass $\left(\mathrm{C}_{\text {mic }}\right.$ and $\left.\mathrm{N}_{\text {mic }}\right)$ is reported in veredas located nearby grazing areas under intensive and technified management, on the soil surface layer $(0-10 \mathrm{~cm})$, especially in the lower slope position, while in agricultural environments, under the same conditions of relief and depth, there is a relative decrease in microbial biomass carbon.
\end{abstract}

KEYWORDS: Biological properties. Enzyme activity. Soil respiration. Organic carbon.

\section{INTRODUCTION}

Land occupation in the Cerrado biome, especially from the second half of the twentieth century, was marked by the expansion and intensification of agricultural activities (KLINK; MACHADO, 2005; DURIGAN et al., 2007), with major changes in production techniques and soil management practices. As a result of this process, the natural (native) vegetation in many sites in the referred region, nearby veredas and other springs, or on the banks of watercourses, has been suppressed over time and replaced by pastures and agricultural crops, with frequent disregard for forest legislation that determines the preservation of these areas.

Many biogeochemical processes that occur in wetlands (and veredas) are directly regulated by several groups of soil microorganisms, aerobic and anaerobic, that can influence the transformations of these chemical pollutants (D'ANGELO; REDDY, 1999). The soil use in these areas or nearby can change the ecosystem as a whole (HOULAHAN et al., 2006), affecting the properties and the quality of soil and water in the veredas, even affecting the environmental context of the river basins where they are located.
The microbial biomass comprises part of the living component of soil organic matter (SOM), being constituted by soil microorganisms and accounting for 2 to $7 \%$ of the organic carbon in the soil environment (GUPTA; ROGET, 2004). This biomass (SMB) is formed mainly by fungi and bacteria that act on important biological processes such as decomposition of organic waste, nutrient cycling (especially $\mathrm{C}$ and $\mathrm{N}$ ), bioremediation of soils contaminated by pollutants, etc. (BALOTA et al., 2003; STOCKDALE; BROOKES, 2006; REIS JUNIOR; MENDES, 2007).

Knowing the roles of microbial biomass in the determination of soil respiration rate $\left(\mathrm{CO}_{2}\right.$ emanation from soil surface) is important for understanding and modeling the processes related to the transformation of organic matter and also for the development of management strategies aimed to improve soil quality and increase carbon (C) sequestration in this environment (WANG et al., 2003). It should also be stressed that soil respiration, as well as many of the factors that determine it, can be influenced and altered by changes in land use (ADACHI et al., 2006).

In turn, the soil enzyme activity is also largely associated with microbial activity, being 
related to important processes such as the decomposition of SOM and nutrient cycling. Thus, the determination of enzyme activity can be a useful tool for the analysis and assessment of the functional diversity of microorganisms, biochemical processes and microbial biology, in addition to providing an indicator of environmental and soil quality (NANNIPIERI et al., 2002).

The microbiological and biochemical soil properties, such as microbial biomass, basal respiration and enzyme activity, as well as the indices obtained from these parameters, are sensitive indicators of soil quality that can be used in the detection, assessment and monitoring of possible environmental changes arising from agricultural land use, providing tools to guide the planning and application of more appropriate and sustainable soil management practices (DORAN; PARKIN, 1994; BENDING et al., 2004; ARAÚJO; MONTEIRO, 2007). Therefore, this study aimed to assess microbiological and biochemical soil properties in wetlands (veredas) located in preserved and disturbed environments (under the impact of farming and grazing areas) in the Cerrado biome.

\section{MATERIAL AND METHODS}

The study was carried out in veredas of the Cerrado biome, in the state of Goiás, Brazil. Soil samples were collected in the months of July and August 2012 (dry season), in areas located between parallels $16^{\circ} 48^{\prime} \mathrm{S}$ and $17^{\circ} 02^{\prime} \mathrm{S}$ and meridians $48^{\circ}$ $41^{\prime} \mathrm{W}$ and $48^{\circ} 49^{\prime} \mathrm{W}$.

The climate in the study region is rainy tropical (Aw in the Köppen climate classification), with an annual average rainfall of $1500 \mathrm{~mm}$. A marked seasonality in rainfall patterns was observed, with well defined rainy (spring and summer) and dry (autumn and winter) seasons (CPRM, 2001). The sampling locations feature a gently undulating plain (slopes from 2 to $6 \%$ ), with altitudes varying from 910 to $950 \mathrm{~m}$, between different veredas.

Three areas were selected for soil sampling, located in the same sub-basin, in preserved and disturbed (anthropized) environments, as follows: a preserved vereda, surrounded by natural vegetation (Cerrado); an disturbed vereda, with grazing (pasture) in its surroundings, and another vereda, also disturbed, with annual crops (agriculture) in its surroundings.

At the time of the study, the entire peripheral region of the vereda located in the preserved environment was covered by natural cerrado vegetation (in a restricted sense), i.e. phytophisiognomies of savanna type, typical of the Cerrado region (RIBEIRO; WALTER, 1998). In the study area, this vegetation extending into a marginal band, beyond the boundary of the permanently flooded marshy area, with well over the (minimum) fifty meters width defined by the Brazilian forest legislation as permanent preservation area or APP (BRASIL, 2012).

The peripheral areas of anthropized veredas were originally recovered by the same type of vegetation, that is, Cerrado in a restricted sense. However, this native vegetation has been removed over time, as a result of the land occupation process in the region (anthropization).

Among the study areas located in disturbed environment, within the sampling period, one had cultivated pastures in its surroundings, predominantly by Brachiaria sp., while in the surroundings of the other area there was farming cultivation of grains (especially corn and soybean crops) in no-tillage system (NT). It should be mentioned that these disturbed veredas were not surrounded by the band of natural vegetation of APP.

Removal of natural vegetation in these areas (deforestation) occurred about 25 years before the sampling conducted for this study. At that time, pastures were initially established under extensive management. Later, a more intensive agricultural management (characterized by greater use of inputs) was adopted, with the adoption of agricultural crops in one area and the use of rotational grazing in the pasture area for 10 and 8 consecutive years (before sampling), respectively.

Soil samples were collected within the boundaries of the veredas under study, these boundaries defined by distinct vegetation observed in the wet environment of the veredas and in the dry adjacent areas, and also by the presence of soils that get saturated in rainy months (hydromorphic soils). Collections were made in a zigzag along reference lines arranged according to their position in the landscape (upper, medium and lower thirds of one of the slopes), according to the approximated direction of drainage of the vereda.

The samples were collected at two depths or soil layers: $0-10 \mathrm{~cm}$ and $10-20 \mathrm{~cm}$. Each sample was composed of five subsamples obtained along the reference lines for sampling, with soil collected in the upper region of the area close to the boundary or edge of the vereda, in the middle portion (middle) and in the lowest portion of the slope, in the region along the thalweg, with three replicates for each collected sample. Particle size fractions of soil at different slope positions, depths of sampling and 
Table 1. Particle size fractions of soil at different slope positions, depths of sampling and conditions of use of the surrounding areas of the veredas.

\begin{tabular}{|c|c|c|c|}
\hline $\begin{array}{l}\text { Condition of soil use of } \\
\text { the surrounding areas }\end{array}$ & Clay & Silt & Sand \\
\hline \multicolumn{4}{|l|}{ 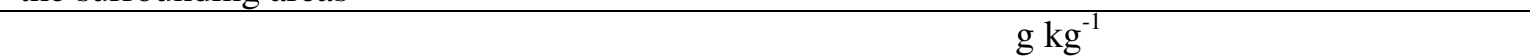 } \\
\hline \multirow{2}{*}{\multicolumn{4}{|c|}{$\frac{\text { Edge of the veredas (upper third of the slope) }}{0-10 \mathrm{~cm}}$}} \\
\hline & & & \\
\hline Preserved & 393 & 130 & 477 \\
\hline Pasture & 340 & 190 & 470 \\
\hline \multirow[t]{2}{*}{ Agriculture } & 387 & 170 & 443 \\
\hline & & $10-20 \mathrm{~cm}$ & \\
\hline Preserved & 393 & 140 & 467 \\
\hline Pasture & 333 & 177 & 490 \\
\hline \multirow[t]{2}{*}{ Agriculture } & 390 & 160 & 450 \\
\hline & \multicolumn{3}{|c|}{ Middle of the veredas (middle third of the slope) } \\
\hline & & $0-10 \mathrm{~cm}$ & \\
\hline Preserved & 390 & 140 & 470 \\
\hline Pasture & 387 & 150 & 463 \\
\hline \multirow{2}{*}{ Agriculture } & 367 & 173 & 460 \\
\hline & & $10-20 \mathrm{~cm}$ & \\
\hline Preserved & 393 & 137 & 470 \\
\hline Pasture & 393 & 163 & 443 \\
\hline \multirow[t]{3}{*}{ Agriculture } & 380 & 207 & 413 \\
\hline & \multicolumn{3}{|c|}{ Bottom of the veredas (lower third of the slope) } \\
\hline & & $0-10 \mathrm{~cm}$ & \\
\hline Preserved & 387 & 143 & 470 \\
\hline Pasture & 400 & 133 & 467 \\
\hline \multirow[t]{2}{*}{ Agriculture } & 350 & 183 & 467 \\
\hline & & $10-20 \mathrm{~cm}$ & \\
\hline Preserved & 383 & 130 & 487 \\
\hline Pasture & 413 & 113 & 473 \\
\hline Agriculture & 383 & 177 & 440 \\
\hline
\end{tabular}

The soil samples were stored in plastic bags in a cooler with ice, protected from heat and direct light until their arrival at the laboratory where they were kept under refrigeration (around $4{ }^{\circ} \mathrm{C}$ ) until the analyzes. The moisture content of the samples was maintained at 50-60 \% of field capacity, by estimating the mass balance of water (gravimetric method) based on the values of field capacity of soil. Then, the samples were sieved and homogenized using a $4 \mathrm{~mm}$ mesh sieve and most of the roots and other plant residues were carefully removed (WARDLE, 1994).

Microbial biomass nitrogen and carbon $\left(\mathrm{N}_{\text {mic }}\right.$ and $\left.\mathrm{C}_{\text {mic }}\right)$ were assessed by the fumigationextraction method, according to Brookes et al. (1985) and Vance et al. (1987), respectively, determined after chloroform fumigation of the samples, which causes the death of microorganisms and release of cellular components. The basal respiration (BR) was determined by means of $\mathrm{CO}_{2}$ evolved from $20 \mathrm{~g}$ of soil incubated during seven days in a tightly closed jar, and carbon dioxide extracted with a solution of potassium hydroxide (WARDLE, 1994).

The metabolic quotient $\left(q \mathrm{CO}_{2}\right)$ was calculated as the ratio between $\mathrm{BR}$ and $\mathrm{C}_{\text {mic }}$ (ANDERSON; DOMSCH, 1993), expressed in this study in milligrams of $\mathrm{C}-\mathrm{CO}_{2}$ per gram of $\mathrm{C}_{\text {mic }}$ per hour (mg C-CO $\mathrm{g}^{-1} \mathrm{C}_{\text {mic }} \mathrm{h}^{-1}$ ). The total organic carbon (TOC) was analyzed by wet oxidation of organic matter $(\mathrm{OM})$, with potassium dichromate in sulfuric acid medium (EMBRAPA, 1997) and the microbial quotient $(q \mathrm{MIC})$ was determined by the $\mathrm{C}_{\text {mic }}$ :TOC ratio (SPARLING, 1992).

The FDA hydrolytic activities in soil were estimated similarly to the method described by Ghini et al. (1998). The procedure consists in the formation of fluorescein from fluorescein diacetate hydrolysis, which is colorless. This compound, when excited at $490 \mathrm{~nm}$, has a maximum emission 
display with green fluorescence display, which can be spectrophotometrically measured. FDA hydrolysis in soil samples was obtained using a standard curve and expressed by the amount (weight) of FDA hydrolyzed per kilogram of soil per hour (mg of hydrolyzed FDA kg-1 of soil $\mathrm{h}^{-1}$ ).

Classical statistics was applied to identify the effects of the different environmental conditions on the assessed variables, with a randomized block design and banded structure, due to the depths of the sampling, in a $3 \times 3$ factorial arrangement (three types of soil use of the surrounding areas and three slop positions). After analysis of variance in each layer or depth of the sampling, the means were compared by Tukey test $(\mathrm{P}<0.05)$. When significant interaction effects between factors were revealed, comparison of means was done after splitting of the degree of freedom, and software SAS (Statistical Analysis System), version 9.1 (SAS INSTITUTE, 2003), was used for the analysis.

\section{RESULTS AND DISCUSSION}

In general, the microbiological and biochemical properties of soil showed alterations in some of the conditions assessed, reflecting, to a greater or lesser extent, the influence of the position in the slope of the vereda and possible changes caused by the management of adjacent lands on soil properties in these environments.

On the surface soil layer $(0-10 \mathrm{~cm})$ there were no significant differences on levels of $\mathrm{C}_{\text {mic }}$ between each type of land use of the surroundings of the veredas, in the highest positions of the slopes (edge and middle), when they were separately assessed (Table 2). In the lower position of the slope of the vereda, $\mathrm{C}_{\text {mic }}$ levels were significantly higher at the edge of the vereda adjacent to the pasture than in the agricultural area.

Several studies conducted in soils of the Cerrado biome, in Brazil, or in tropical soils located in other terrestrial ecosystems, as well as coastal wetlands (mangroves), especially on surface layers, indicate a significant decrease in soil microbial biomass - SMB $\left(\mathrm{C}_{\text {mic }}\right.$ and/or $\left.\mathrm{N}_{\text {mic }}\right)$ in agricultural areas or in areas disturbed by deforestations and other soil uses, compared to similar soils under native vegetation (LUIZAO et al., 1992; BEHERA; SAHANI, 2003; DINESH et al., 2004; CARDOSO et al., 2009; LOURENTE et al., 2011). Nevertheless, research conducted in tropical soils in forest ecosystems in Latin America (PFENNING et al., 1992; GROFFMAN et al., 2001) and in the
Brazilian Cerrado (CARNEIRO et al., 2008; ALVES et al., 2011; MUNIZ et al., 2011) demonstrate that, in some cases, a significant increase in SMB $\left(\mathrm{C}_{\text {mic }}\right)$ may occur in grazing areas, compared to similar soils under native vegetation.

Some of the referred studies emphasize this increase as a probable consequence of intense vegetative growth and biomass production of forage grasses, especially through its root system, which leads to higher $\mathrm{C}$ input to the soil, activating soil microbiota (TATE, 1992; CARNEIRO et al., 2008; ALVES et al., 2011). However, Muniz et al. (2011) also reported a decrease in $\mathrm{C}_{\text {mic }}$ levels in soils of degraded pastures, under continuous grazing, compared to land under natural conditions (cerrado vegetation) and properly managed pastures.

No significant changes were observed in $\mathrm{C}_{\text {mic }}$ levels along the toposequence (slopes) in the preserved ecosystem, while in the farming and grazing areas (anthropized), $\mathrm{C}_{\text {mic }}$ levels were significantly higher on the edge of the vereda adjacent to the agricultural area and in the lowest portion of the slope of the vereda under the influence of pastures (Table 2). In a study of SMB in toposequence performed in a grazing area, higher $\mathrm{C}_{\text {mic }}$ values were observed in hydromorphic soil (Gleysol), near the Brazilian coast, in the lower position of the slope (GONÇALVES et al., 2007).

The metabolic quotient $\left(q \mathrm{CO}_{2}\right)$, up to a depth of $10 \mathrm{~cm}$ and at each position of the slopes did not vary among the different soil uses of the surroundings. In the veredas adjacent to agricultural areas and the natural environment there were higher values for $q \mathrm{CO}_{2}$ at the lowest position of slope, while in the area adjacent to pastures, there were no significant differences for this index along the slope (Table 2).

Increase in $\mathrm{N}_{\text {mic }}$ levels was observed compared to the preserved and agricultural areas in the area surrounding the pastures, on the surface soil layer $(0-10 \mathrm{~cm})($ Table 3$)$. It should be mentioned that, at the time of soil sampling, most of the grazing area of the study has already been under intensive and irrigated rotational grazing, for dairy production, for around eight years, receiving regular applications (in the coverage level) of nitrogen fertilizers.

On the surface soil layer $q \mathrm{MIC}$ was generally higher in the vereda located in the agricultural environment, and no differences were detected between the preserved environment and the area surrounded by pastures (Table 3 ). 
Table 2. Microbial biomass carbon $\left(\mathrm{C}_{\text {mic }}\right)$, microbial biomass $\mathrm{C}: \mathrm{N}$ ratio $\left(\mathrm{C}_{\text {mic }}: \mathrm{N}_{\text {mic }}\right)$ and metabolic quotient $\left(q \mathrm{CO}_{2}\right)$ at different positions of slope and under different conditions of soil use/management of the surrounding area, in the $0-10 \mathrm{~cm}$ layer.

\begin{tabular}{|c|c|c|c|c|c|}
\hline \multirow{2}{*}{ Position in the slope } & \multicolumn{5}{|c|}{ Condition of soil use of the surrounding area } \\
\hline & \multicolumn{2}{|c|}{ Preserved } & \multicolumn{2}{|c|}{ Pasture } & Agriculture \\
\hline \multicolumn{6}{|c|}{$\mathrm{C}_{\mathrm{mic}}\left(\mathrm{mg} \mathrm{C} \mathrm{kg}^{-1}\right.$ de soil $)$} \\
\hline Upper & 263.17 a & A & $225.70 \mathrm{ab}$ & A & 531.58 a $\mathrm{A}$ \\
\hline Middle & 183.72 a & A & $163.87 \mathrm{~b}$ & A & $263.26 \mathrm{~b} \quad \mathrm{~A}$ \\
\hline Lower & $255.68 \mathrm{a}$ & $\mathrm{AB}$ & $428.85 \mathrm{a}$ & A & 159.45 b B \\
\hline \multicolumn{6}{|c|}{$\mathrm{C}_{\text {mic }}: \mathrm{N}_{\text {mic }}$} \\
\hline Upper & $9.84 \mathrm{a}$ & A & $4.01 \mathrm{a}$ & A & 16.71 a $\mathrm{A}$ \\
\hline Middle & $4.90 \mathrm{a}$ & A & $2.19 \mathrm{~b}$ & A & 4.40 a $\mathrm{A}$ \\
\hline Lower & $4.65 \mathrm{a}$ & A & $3.44 \mathrm{a}$ & A & 4.55 a $\mathrm{A}$ \\
\hline \multicolumn{6}{|c|}{$q \mathrm{CO}_{2}\left(\mathrm{mg} \mathrm{C}-\mathrm{CO}_{2} \mathrm{~g}^{-1} \mathrm{C}_{\text {mic }} \mathrm{h}^{-1}\right)$} \\
\hline Upper & $7.36 \mathrm{~b}$ & A & $16.19 \mathrm{a}$ & A & $3.90 \mathrm{~b} \quad \mathrm{~A}$ \\
\hline Middle & $6.97 \mathrm{~b}$ & A & 20.23 a & A & $9.30 \mathrm{~b} \quad \mathrm{~A}$ \\
\hline Lower & $18.06 \mathrm{a}$ & A & $16.53 \mathrm{a}$ & A & 26.54 a $\mathrm{A}$ \\
\hline
\end{tabular}

Lowercase letters compare positions of the slope (columns) and uppercase letters compare the soil uses of the surroundings (lines). Means followed by the same letter do not differ statistically by Tukey test $(\mathrm{P}<0.05)$.

Table 3. Microbial biomass nitrogen $\left(\mathrm{N}_{\mathrm{mic}}\right)$, FDA hydrolytic activities in soil and microbial quotient ( $q$ MIC) under different conditions of soil use of the surroundings, in the $0-10 \mathrm{~cm}$ layer.

\begin{tabular}{lcrc}
\hline $\begin{array}{l}\text { Condition of soil use of the } \\
\text { surrounding areas }\end{array}$ & $\begin{array}{c}\mathrm{N}_{\text {mic }} \\
\left(\mathrm{mg} \mathrm{N} \mathrm{kg}^{-1} \text { of soil }\right)\end{array}$ & $\begin{array}{c}\text { FDA hydrolysis } \\
\left(\mathrm{mg} \mathrm{of} \mathrm{hydrolyzed} \mathrm{FDA}_{\mathrm{kg}^{-1} \text { of soil h}}\right)^{-1}\end{array}$ & $\begin{array}{c}q \mathrm{MIC} \\
(\%)\end{array}$ \\
\hline Preserved & $41.31 \mathrm{~b}$ & $158.16 \mathrm{~b}$ & $0.77 \mathrm{~b}$ \\
Pasture & $84.53 \mathrm{a}$ & $219.51 \mathrm{a}$ & $0.77 \mathrm{~b}$ \\
Agriculture & $50.07 \mathrm{~b}$ & $217.99 \mathrm{a}$ & $1.24 \mathrm{a}$ \\
\hline
\end{tabular}

Means followed by the same letter do not differ statistically by Tukey test $(\mathrm{P}<0.05)$. Means in the positions in the slope.

Studies conducted in subtropical soils in southern Brazil, in the United States and in New Zealand showed that the levels of $\mathrm{N}_{\text {mic }}$ (and in some cases, also of $\mathrm{C}_{\text {mic }}$ ) can be significantly higher than in grazing ecosystems in use (under appropriate grazing) than in soils under agricultural areas or under natural vegetation. This feature is related, among other factors, to the possible use of fertilizers and to the presence of herds, which, by producing manure, promote the supply of available nutrients, with impact on soil microbial populations (GHANI et al., 2003; WANG et al., 2006; GARCIA; NAHAS, 2007).

Analyzes of surface layers (up to $10 \mathrm{~cm}$ depth) in lowlands (hydromorphic soils) in areas of subtropical climate in southern Brazil used for the cultivation of rice showed that conservation management systems with minimum tillage, provided, on the surface, a microbial biomass similar to that of similar soils under natural conditions, or even greater, considering specifically $\mathrm{N}_{\text {mic }}$ levels (SANTOS et al., 2004). In some cases, it can be affirmed that the more conservative the soil management is, the greater the accumulation of $\mathrm{N}$ on the surface, immobilized in the SMB (FIGUEIREDO et al., 2007).

The determination of the SMB $\left(\mathrm{C}_{\text {mic }}\right.$ and $\mathrm{N}_{\text {mic }}$ ) is a very sensitive parameter to changes in soil caused by land management, and responds to environmental factors such as changes in soil moisture regime. Thus, significant changes in SMB can be detected before the occurrence of any measurable changes in organic matter (total $\mathrm{C}$ and $\mathrm{N}$ ), thus allowing the adoption of corrective and adjustment measurements that prevent more severe loss of soil quality (TÓTOLA; CHAER, 2002).

The lowest value for the $\mathrm{C}_{\text {mic }}: \mathrm{N}_{\text {mic }}$ ratio on the surface soil layer was observed in the middle position of the slope of the vereda nearby the grazing areas (Table 2). On the subsurface layer $(10-20 \mathrm{~cm})$, in turn, a higher $\mathrm{C}_{\text {mic }}: \mathrm{N}_{\text {mic }}$ ratio was generally observed in the vereda in grazing areas and a lower ratio was observed in the vereda nearby agricultural crops (Figure 1). 


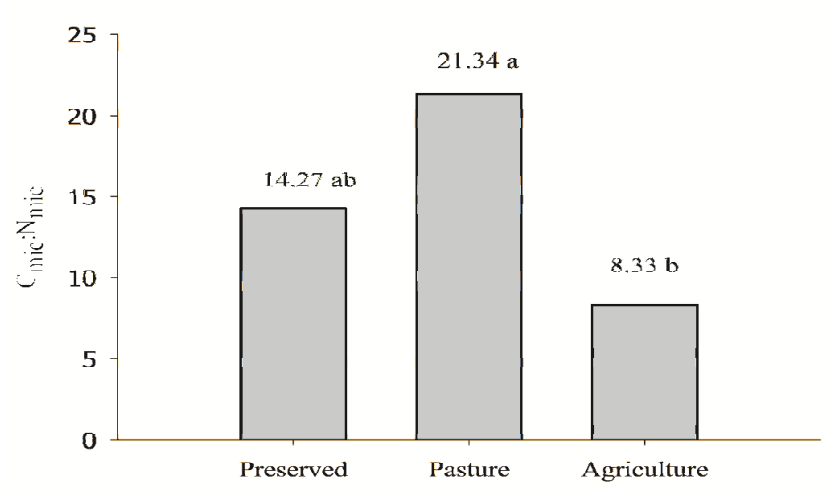

Figure 1. $\mathrm{C}_{\text {mic }}: \mathrm{N}_{\text {mic }}$ ratio under the different conditions of soil use of the surrounding areas of the veredas, on the 10-20 cm layer. Means followed by the same letter do not differ statistically by Tukey test $(\mathrm{P}<0.05)$. Means in the positions in the slope.

The $\mathrm{C}_{\text {mic }}: \mathrm{N}_{\text {mic }}$ ratio is often used to describe the structure and status of the soil microbial community (MOORE et al., 2000), or as a potential indicator of environmental disturbance (DINESH et al., 2004). In hydromorphic soils, in general, there is a decrease in the microbiota composed of fungi and actinomycetes, while cyanobacteria and anaerobic bacteria benefit from these conditions (TSAI et al., 1992). In these environments, the changes in the microbial biomass $\mathrm{C}: \mathrm{N}$ ratio may indicate structural differences in communities of microorganisms, caused by the influence of various environmental factors, which makes it possible to differentiate ecosystems that although comparable may present specific features and conditions (TRUU et al., 2009).

The $\mathrm{C}_{\text {mic }}: \mathrm{N}_{\text {mic }}$ ratio is affected by soil properties such as moisture, texture, $\mathrm{pH}$, availability of $\mathrm{C}$ and $\mathrm{N}$ in the biomass microorganisms
$\left(\mathrm{C}_{\text {mic }}\right.$ : TOC and $\mathrm{N}_{\text {mic }}$ :total $\left.\mathrm{N}\right)$, incorporation of $\mathrm{N}$ by soil fungi and proportion in distribution of microorganisms in number and diversity (ANDERSON; DOMSCH, 1980; CAMPBELL et al., 1991; MOORE et al., 2000) and may therefore be influenced by natural environmental factors or those related to soil use and management.

As for the 10-20 cm layer, separate analysis of each position in the slope did not detect significant changes in microbial quotient between the different land uses of the surroundings of the study areas (Table 4). In the preserved environment, however, a progressive decrease in $q$ MIC was observed along the toposequence towards the lowest portion of the slope, while in the disturbed areas (farming and grazing) this change was not significant by the F test (Table 4), due to the high variability in these areas.

Table 4. Basal soil respiration (BR), FDA hydrolytic activities in soil and microbial quotient $(q \mathrm{MIC})$ in different positions of the slope and conditions of soil use of the surroundings, on the $10-20 \mathrm{~cm}$ layer.

\begin{tabular}{|c|c|c|c|c|c|}
\hline \multirow{2}{*}{ Position in the slope } & \multicolumn{5}{|c|}{ Condition of soil use of the surroundings } \\
\hline & Preserv & & Pastul & & Agriculture (farming) \\
\hline \multicolumn{6}{|c|}{$\mathrm{BR}\left(\mathrm{mg} \mathrm{C}-\mathrm{CO}_{2} \mathrm{~kg}^{-1}\right.$ de soil h $\left.\mathrm{h}^{-1}\right)$} \\
\hline Upper & $0.84 \mathrm{~b}$ & A & $2.48 \mathrm{a}$ & A & 1.82 a $\mathrm{A}$ \\
\hline Middle & $0.97 \mathrm{~b}$ & A & $1.81 \mathrm{a}$ & A & 1.86 a $\mathrm{A}$ \\
\hline Lower & 20.95 a & A & $3.76 \mathrm{a}$ & $\mathrm{B}$ & 1.65 a $\mathrm{B}$ \\
\hline \multicolumn{6}{|c|}{ FDA hydrolysis (mg of hydrolyzed FDA kg ${ }^{-1}$ of soil $\mathrm{h}^{-1}$ ) } \\
\hline Upper & $96.11 \mathrm{~b}$ & $\mathrm{~B}$ & $225.74 \mathrm{ab}$ & A & 250.45 a $\mathrm{A}$ \\
\hline Middle & $188.83 \mathrm{a}$ & B & $275.71 \mathrm{a}$ & A & 214.78 a $\mathrm{AB}$ \\
\hline Lower & $66.51 \mathrm{~b}$ & B & $208.89 \mathrm{~b}$ & A & 110.68 b $\quad B$ \\
\hline \multicolumn{6}{|c|}{$q \mathrm{MIC}(\%)$} \\
\hline Upper & $1.38 \mathrm{a}$ & $\mathrm{A}$ & $2.79 \mathrm{a}$ & A & 1.12 a $\mathrm{A}$ \\
\hline Middle & $0.80 \mathrm{ab}$ & A & $0.80 \mathrm{a}$ & A & 2.27 a A \\
\hline Lower & $0.24 \mathrm{~b}$ & A & $0.32 \mathrm{a}$ & A & 0.59 a A \\
\hline
\end{tabular}

Lowercase letters compare positions of the slope (columns) and uppercase letters compare the soil uses of the surroundings (lines). Means followed by the same letter do not differ statistically by Tukey test $(\mathrm{P}<0.05)$. 
Unlike this paper, other studies on Brazilian and Indian tropical soils that compared areas under native vegetation (forests or savannas) for agricultural use or forest crops, at surface soil layers, had an $q \mathrm{MIC}$ behavior similar to the results obtained for the SMB, with lower values in anthropized areas (D'ANDRÉA et al., 2002; BEHERA; SAHANI, 2003; FONSECA et al., 2007; CARDOSO et al., 2009). In such cases, the decrease in $q$ MIC may indicate a probable stress condition for the microbial population due to anthropogenic disturbances due to factors such as reduction of the quantity and quality of organic substrate, nutritional deficiencies, changes in $\mathrm{pH}$, presence of pollutants, etc (WARDLE, 1994; CARDOSO et al., 2009).

Changes in microbial quotient may also reflect the increases in SOM, efficient conversion of soil organic carbon (OC) in $\mathrm{C}_{\text {mic }}$, stabilization of $\mathrm{OC}$ by mineral soil fractions and also possible losses of soil C (SPARLING, 1992). This decrease in carbon concentrations occurs in soils of some veredas of the Cerrado biome, where agricultural environments showed lower TOC levels than the preserved environment, notably in the lowest slopes of the veredas (SOUSA et al., 2011).

On the surface layer $(0-10 \mathrm{~cm})$, there were no significant differences in BR rates between the environments, or else, under the different conditions of soil use of the surroundings of the veredas. On the subsurface layer, however, only in the lowest position of the slope, there was a higher BR rate in the preserved vereda, without significant differences between the disturbed environments for this slope position (Table 4). Lower soil BR rates were observed in the highest and medium positions, compared to the lowest position of the slope, and there were no changes in this attribute along the slope in places adjacent to pastures and agricultural crops (Table 4).

In a comparison of tropical soils covered by cultivated pastures and native forest vegetation in the Pantanal region in state of Mato Grosso do Sul, Cardoso et al. (2009) found no significant differences in BR rates in some sites between the two conditions of land use, at the $0-10 \mathrm{~cm}$ depth. However, in some situations, there may be variations of this attribute on the $10-20 \mathrm{~cm}$ layer. Toposequence study of different classes of Brazilian tropical soils used in pastures, including hydromorphic soils, demonstrate that BR rates may vary according to the type of soil, toposequence location, sampling depth and time of the year, in this case, being mainly influenced by soil moisture (GONÇALVES et al., 2007).
A more efficient SMB loses lower relative amounts of $\mathrm{C}$ in the form of $\mathrm{CO}_{2}$ (with respiration) and incorporates more $\mathrm{C}$ to the microbial tissues (REIS JUNIOR; MENDES, 2007). High metabolic quotients indicate microbial communities at early stages of development, with a higher percentage of active microorganisms compared to inactive, or are an indication of microbial populations under some sort of metabolic stress (ANDERSON; DOMSCH, 1993). However, these values should be compared on the same type of soil, once other factors, besides those that promote stress, may impact the SMB (MOREIRA; SIQUEIRA, 2006), and its respiratory activity.

Soil respiration can be considered a sensitive indicator of the influence of abiotic factors on soil environment, decomposition of waste, metabolic quotient and ecosystem disturbances (PAUL et al., 1999; SHENG et al., 2010). However, their values must be carefully interpreted (Totola; CHAER, 2002), since high respiration rates can indicate both ecological disturbance and high level of productivity ecosystem (ISLAM; WEIL, 2000). These disorders can be caused, for example, by pesticides, chemical fertilizers or organic waste.

Regarding FDA hydrolytic activities in soil, on the surface layer higher FDA hydrolysis values were observed in disturbed veredas (farming and grazing), compared to the preserved environment (Table 3). Following the analysis of surface soils (up to $15 \mathrm{~cm}$ depth), in temperate conditions in New Zealand, Stark et al. (2007) reported the increase in FDA hydrolysis in agricultural soils with application of mineral fertilizers, compared to agricultural areas under organic management.

Higher FDA hydrolysis was detected at a $10-20 \mathrm{~cm}$ depth in agricultural and livestock environments (anthropized), especially at the highest positions (edge and medium) of the slopes. It should be noted that there was no significant difference for this attribute in the lowest slope position between the agricultural and preserved environments (Table 4).

Unlike the results of the present study, other studies carried out in Brazilian tropical soils, in savannas (Cerrado) (EVANGELISTA et al., 2012) and tropical forest (Mata Atlântica) (SANT'ANNA et al., 2009), or in agroforestry areas established for the protection of watercourses in the region of cold continental climate of North America (UDAWATTA et al., 2009), compared to similar soils under agricultural use or under forest cultivation for timber production, on surface soil layer $(0-10 \mathrm{~cm})$, found higher enzyme activity (determined by FDA hydrolysis) in soils under 
native vegetation or agroforestry. However, Sant'anna et al. (2009) mentioned the possibility that the pattern of response of the enzyme activity measured by FDA hydrolysis to the practices of management of agricultural soils would change depending on the seasons (dry and rainy), which could be considered a limitation of this parameter for monitoring changes in soil quality.

Therefore, the study of Evangelista et al. (2012) with soils of Cerrado found a significant increase in FDA hydrolysis in agricultural soils (sugar cane crops) in winter (dry season), in areas where straw is not burnt as fuel. The authors noticed that these soils had enzymatic features similar to the FDA hydrolysis results obtained in areas covered by native vegetation, though with lower enzyme activity, so that the FDA hydrolysis could possibly be subject to seasonal variations.

The use of enzyme activities (including FDA hydrolysis) as indicators of soil quality can be quite troublesome, since in many cases it is difficult to elucidate possible changes in enzyme activity in response to a given factor, or even establish relations of cause and effect between the occurrence of a disturbing event and changes in soil enzyme activity (GIANFREDA et al., 2005). However, fluorescein diacetate hydrolysis is said to be a sensitive method to estimate microbial activity in hydromorphic soil (Planosol) of subtropical lowlands in southern Brazil, constituting a bioindicator of soil quality in areas subjected to different types of agricultural management under those conditions (MATTOS et al., 2009).

\section{CONCLUSIONS}

The use of surrounding land for livestock grazing increases the levels of microbial carbon on the surface soil layer, at the lowest position of the slope of the veredas, compared to agricultural use. Furthermore, the use of pastures in adjacent areas raises $\mathrm{N}$ levels of the microbial biomass on the surface soil layer of the veredas.

The microbiological and biochemical properties of the soil of veredas, related to the microbial biomass and its enzyme and respiratory activity are altered as a result of agricultural and livestock activities performed in adjacent areas, especially on the surface soil layer and on the lower portion of slopes.

The microbiological and biochemical properties are appropriate indicators of environmental modifications and impacts caused by the land use in the surroundings of these ecosystems.

\section{ACKNOWLEDGMENTS}

To the Foundation for Research Support of the State of Goiás (FAPEG), for offering a $\mathrm{PhD}$ scholarship to the first author. To the Foundation for Research Support (FUNAPE/UFG), to the Laboratories of Soil Microbiological and Biochemical Analyzes and the Laboratories of Soil and Foliar Analyzes of Escola de Agronomia da Universidade Federal de Goiás (LASF/EA/UFG) and to the Laboratory of Agri-Environmental Analyzes (LAA) of Embrapa Arroz e Feijão, for material and technical support.

RESUMO: As veredas são ecossistemas úmidos, normalmente associados à presença de solos hidromórficos, que ocorrem com frequência nas proximidades das nascentes e cursos d'água da região do Cerrado. O objetivo deste trabalho foi avaliar atributos microbiológicos e bioquímicos do solo em áreas úmidas (veredas) localizadas em ambientes conservados e antropizados (em áreas agrícolas e pastagens), no bioma Cerrado. Amostras de solo foram coletadas nas profundidades de 0-10 cm e 10-20 cm, ao longo de linhas de referência dispostas, segundo sua posição no relevo, nas posições superior, média e inferior de uma das vertentes. Foram determinados o carbono orgânico total do solo, carbono e nitrogênio da biomassa microbiana $\left(\mathrm{C}_{\text {mic }}\right.$ e $\left.\mathrm{N}_{\text {mic }}\right)$, relação $\mathrm{C}: \mathrm{N}$ da biomassa microbiana, quociente microbiano, respiração basal, quociente metabólico e atividade enzimática total do solo. Os solos de veredas vizinhas a ambientes agropecuários apresentaram variações em seus atributos biológicos, comparativamente a ecossistemas conservados. Em veredas adjacentes a pastagens sob manejo intensivo tecnificado, na camada superficial do solo $(0-10 \mathrm{~cm})$, ocorreu o incremento da biomassa microbiana $\left(\mathrm{C}_{\text {mic }}\right.$ e $\mathrm{N}_{\text {mic }}$ ), notadamente na posição inferior do relevo, enquanto em ambientes agrícolas, nas mesmas condições de relevo e profundidade, observou-se uma diminuição relativa do carbono da biomassa microbiana.

PALAVRAS-CHAVE: Atributos biológicos. Atividade enzimática. Respiração do solo. Carbono orgânico. 


\section{REFERENCES}

ADACHI, M.; BEKKU, Y. S.; RASHIDAH, W.; OKUDA, T.; KOIZUMI, H. Differences in soil respiration between different tropical ecosystems. Applied Soil Ecology, Stillwater, v. 34, n. 2-3, p. 258-265, 2006. http://dx.doi.org/10.1016/j.apsoil.2006.01.006

ALVES, T. S; CAMPOS, L. L.; ELIAS NETO, N.; MATSUOKA, M.; LOUREIRO, M. F. Biomassa e atividade microbiana de solo sob vegetação nativa e diferentes sistemas de manejos. Acta Scientiarum. Agronomy, Maringá, v. 33, n. 2, p. 341-347, 2011.

ANDERSON, J. P. E.; DOMSCH, K. H. Quantities of plant nutrients in the microbial biomass of selected soils. Soil Science, Philadelphia, v. 130, n. 4, p. 211-216, 1980. http://dx.doi.org/10.1097/00010694-19801000000008

ANDERSON, T.-H.; DOMSCH, K. H. The metabolic quotient for $\mathrm{CO}_{2}\left(q \mathrm{CO}_{2}\right)$ as a specific activity parameter to assess the effects of environmental conditions, such as $\mathrm{pH}$, on the microbial biomass of forest soils. Soil Biology \& Biochemistry, Oxford, v. 25, n. 3, p. 393-395, 1993. http://dx.doi.org/10.1016/00380717(93)90140-7

ARAÚJO, A. S. F.; MONTEIRO, R. T. R. Indicadores biológicos de qualidade do solo. Bioscience Journal, Uberlândia, v. 23, n. 3, p. 66-75, 2007.

BALOTA, E. L.; COLOZZI-FILHO, A.; ANDRADE, D. S.; DICK, R. P. Microbial biomass in soils under different tillage and crop rotation systems. Biology and Fertility of Soils, Firenzi, v. 38, n. 1, p. 15-20, 2003.

BEHERA, N.; SAHANI, U. Soil microbial biomass and activity in response to Eucalyptus plantation and natural regeneration on tropical soil. Forest Ecology and Management, Fort Collins, v. 174, n. 1-3, p. 1-11, 2003. http://dx.doi.org/10.1016/S0378-1127(02)00057-9

BENDING, G. D.; TURNER, M. K.; RAYNS, F.; MARX, M. C.; WOOD, M. Microbial and biochemical soil quality indicators and their potential for differentiating areas under contrasting agricultural management regimes. Soil Biology \& Biochemistry, Brisbane, v. 36, n. 11, p. 1785-1792, 2004. http://dx.doi.org/10.1016/j.soilbio.2004.04.035

BRASIL. Lei $\mathbf{n}^{\circ}$ 12651, de 25/5/2012 e Lei $\mathbf{n}^{\circ}$ 12727, de 17/10/2012. Dispõem sobre a proteção da vegetação nativa e alteram a respectiva legislação. Brasil, 2012.

BROOKES, P. C.; LANDMAN, A.; PRUDEN, G.; JENKINSON, D.S. Chloroform fumigation and the release of soil nitrogen: A rapid direct extraction method to measure microbial biomass nitrogen in soil. Soil Biology \& Biochemistry, Oxford, v. 17, n. 6, p. 837-842, 1985. http://dx.doi.org/10.1016/0038-0717(85)90144-0

CAMPBELL, C. A.; BIEDERBECK, V. O.; ZENTNER, R. P.; LAFOND, G. P. Effect of crop rotations and cultural practices on soil organic matter, microbial biomass and respiration in a thin black Chernozem.

Canadian Journal of Soil Science, Ottawa, v. 71, n. 3, p. 363-376, 1991. http://dx.doi.org/10.4141/cjss91-035

CARDOSO, E. L.; SILVA, M. L. N.; MOREIRA, F. M. S.; CURI, N. Atributos biológicos indicadores da qualidade do solo em pastagem cultivada e nativa no Pantanal. Pesquisa Agropecuária Brasileira, Brasília, v. 44, n. 6, p. 631-637, 2009. http://dx.doi.org/10.1590/S0100-204X2009000600012

CARNEIRO, M. A. C.; ASSIS, P. C. R; MELO, L. B. C.; PEREIRA, H. S.; PAULINO, H. B.; SILVEIRA NETO, A. N. Atributos bioquímicos em dois solos de Cerrado sob diferentes sistemas de manejo e uso.

Pesquisa Agropecuária Tropical, Goiânia, v. 38, n. 4, p. 276-283, 2008.

CPRM - SERVIÇO GEOLÓGICO DO BRASIL. BAÊTA Jr., J.D.A. (Org.). Programa Levantamentos Geológicos Básicos do Brasil. Brasília: CPRM, 2001. (Folha SE. 22 Goiânia). 
D’ANDRÉA, A. F.; SILVA, M. L. N.; CURI, N.; SIQUEIRA, J. O.; CARNEIRO, M. A. C. Atributos biológicos indicadores da qualidade do solo em sistemas de manejo na Região do Cerrado no sul do Estado de Goiás. Revista Brasileira de Ciência do Solo, Viçosa, v. 26, n. 4, p. 913-923, 2002.

D'ANGELO, E. M.; REDDY, K. R. Regulators of heterotrophic microbial potentials in wetland soils. Soil Biology \& Biochemistry, Brisbane, v. 31, n. 6, p. 815-830, 1999. http://dx.doi.org/10.1016/S00380717(98)00181-3

DINESH, R.; CHAUDHURI, S. G.; GANESHAMURTHY, A.N.; PRAMANIK, S.C. Biochemical properties of soils of undisturbed and disturbed mangrove forests of South Andaman (India). Wetlands Ecology and Management, Dordrech, v. 12, n. 5 , p. 309-320, 2004.

DORAN, J. W.; PARKIN, T. B. Defining and assessing soil quality. In: DORAN, J. W.; COLEMAN, D. C.; BEZDICEK, D. F.; STEWART, B.A. (Ed.). Defining soil quality for a sustainable environment. Madison: Soil Science Society of America, 1994. p. 3-21. (SSSA Special Publication, 35).

DURIGAN, G.; SIQUEIRA, M. F.; FRANCO, G. A. D. C. Threats to the Cerrado remnants of the state of São Paulo, Brazil. Scientia Agricola, Piracicaba, v. 64, n. 4, p. 355-363, 2007. http://dx.doi.org/10.1590/s010390162007000400006

EMBRAPA - EMPRESA BRASILEIRA DE PESQUISA AGROPECUÁRIA. CLAESSEN, M.E.C. (Org.). Manual de métodos de análise de solo. 2. ed. Rio de Janeiro: Centro Nacional de Pesquisa de Solos, 1997. $212 \mathrm{p}$.

EVANGELISTA, C. R.; PARTELLI, F. L.; FERREIRA, E. P. B.; CORRECHEL, V. Atividade enzimática do solo sob sistema de produção orgânica e convencional na cultura da cana-de-açúcar em Goiás. Semina: Ciências Agrárias, Londrina, v. 33, n. 4, p. 1251-1262, 2012. http://dx.doi.org/10.5433/16790359.2012v33n4p1251

FIGUEIREDO, C. C.; RESCK, D. V. S.; GOMES, A. C.; FERREIRA, E. A. B.; RAMOS, M. L. G. Carbono e nitrogênio da biomassa microbiana em resposta a diferentes sistemas de manejo em um latossolo vermelho no Cerrado. Revista Brasileira de Ciência do Solo, Viçosa, v. 31, n. 3, p. 551-562, 2007.

FONSECA, G. C.; CARNEIRO, M. A. C.; COSTA, A. R.; OLIVEIRA, G. C.; BALBINO, L. C. Atributos físicos, químicos e biológicos de Latossolo Vermelho Distrófico de Cerrado sob duas rotações de cultura. Pesquisa Agropecuária Tropical, Goiânia, v. 37, n. 1, p. 22-30, 2007.

GARCIA, M. R. L.; NAHAS, E. Biomassa e atividades microbianas em solo sob pastagem com diferentes lotações de ovinos. Revista Brasileira de Ciência do Solo, Viçosa, v. 31, n. 2, p. 269-276, 2007.

GHANI, A.; DEXTER M.; PERROTT K.W. Hot-water extractable carbon in soils: a sensitive measurement for determining impacts of fertilisation, grazing and cultivation. Soil Biology \& Biochemistry, Brisbane, v. 35, n. 9, p. 1231-1243, 2003. http://dx.doi.org/10.1016/S0038-0717(03)00186-X

GHINI, R.; MENDES, M. D. L.; BETTIOL, W. Método de hidrólise de diacetato de fluoresceína (FDA) como indicador da atividade microbiana no solo e supressividade a Rhizoctonia solani. Summa Phytopathologica, Botucatu, v. 24, n. 3-4, p. 239-242, 1998.

GIANFREDA, L.; RAO, M. A.; PIOTROWSKA, A.; PALUMBO, G.; COLOMBO. Soil enzyme activities as affected by anthropogenic alterations: intensive agricultural practices and organic pollution. Science of the Total Environment, Madison, v. 341, n. 1-3, p. 265-279, 2005.

http://dx.doi.org/10.1016/j.scitotenv.2004.10.005 
GONÇALVES, A. S.; MONTEIRO, M. T.; GUERRA, J. G. M.; COSTANTINI, A. O.; DE-POLLI, H. Biomassa microbiana em amostras umedecidas após secagem ao ar de solos de toposeqüência de pastagens. Ciencia del Suelo, Oliveros, v. 25, n. 1, p. 81-87, 2007.

GROFFMAN, P. M.; McDOWELL, W. H.; MYERS, J. C.; MERRIAM, J. L. Soil microbial biomass and activity in tropical riparian forests. Soil Biology \& Biochemistry, Brisbane, v. 33, n. 10, p. 1339-1348, 2001. http://dx.doi.org/10.1016/S0038-0717(01)00039-6

GUPTA, V. V. S. R.; ROGET, D. K. Understanding soil biota and biological functions: management of soil biota for improved benefits to crop production and environmental health. In: LINES-KELLY, R. (Ed.). Soil Biology in Agriculture. Orange: NSW Department of Primary Industries, 2004. p. 1-7.

HOULAHAN, J. E.; KEDDY, P. A.; MAKKAY, K.; FINDLAY, C. S. The effects of adjacent land use on wetland species richness and community composition. Wetlands, Fargo, v. 26, n. 1, p. 79-96, 2006. http://dx.doi.org/10.1672/0277-5212(2006)26[79:TEOALU]2.0.CO;2

ISLAM, K. R.; WEIL, R. R. Land use effects on soil quality in a tropical forest ecosystem of Bangladesh. Agriculture, Ecosystems and Environment, Amsterdam, v. 79, n. 1, p. 9-16, 2000. http://dx.doi.org/10.1016/S0167-8809(99)00145-0

KLINK, C. A.; MACHADO, R. B. Conservation of the Brazilian Cerrado. Conservation Biology, Malden, v. 19, n. 3, p. 707-713, 2005. http://dx.doi.org/10.1111/j.1523-1739.2005.00702.x

LOURENTE, E. R. P.; MERCANTE, F. M.; ALOVISI, A. M. T.; GOMES, C. F.; GASPARINI, A. S.; NUNES, C. M. Atributos microbiológicos, químicos e físicos de solo sob diferentes sistemas de manejo e condições de Cerrado. Pesquisa Agropecuária Tropical, Goiânia, v. 41, n. 1, p. 20-28, 2011.

LUIZAO, R. C. C.; BONDER, T. A.; ROSSWAL, T. Seasonal variation of soil microbial biomass - The effects of clearfelling a tropical rainforest and establishment of pasture in the central Amazon. Soil Biology $\&$ Biochemistry, Oxford, v. 24, n. 8, p. 805-813, 1992. http://dx.doi.org/10.1016/0038-0717(92)90256-W

MATTOS, M. L. T.; SANTOS, I. M. B.; ALMEIDA, M. T. Hidrólise de diacetato de fluoresceína como bioindicador da qualidade de solo de várzea subtropical. Pelotas: Embrapa Clima Temperado, 2009. 4 p. (Comunicado Técnico, 231).

MOORE, J. M.; KLOSE, S.; TABATABAI, M. A. Soil microbial biomass carbon and nitrogen as affected by cropping systems. Biology and Fertility of Soils, Firenzi, v. 31, n. 3-4, p. 200-210, 2000.

MOREIRA, F. M. S.; SIQUEIRA, J. O. Microbiologia e Bioquímica do solo. 2. ed. Lavras: Ed. UFLA, 2006. $729 \mathrm{p}$.

MUNIZ, L. C.; MADARI, B. E.; TROVO, J. B. F; CANTANHÊDE, I. S. L.; MACHADO, P. L. O. A.; COBUCCI, T.; FRANÇA, A. F. S. Soil biological attributes in pastures of different ages in a crop-livestock integrated system. Pesquisa Agropecuária Brasileira, Brasília, v. 46, n. 10, p. 1262-1268, 2011.

NANNIPIERI, P.; KANDELER, E.; RUGGIERO, P. Enzyme activities and microbiological and biochemical process in soil. In: BURNS, R. G.; DICK, R.P. (Ed.). Enzymes in the environment: activity, ecology and application. New York: Marcel Dekker, Inc., 2002. chap. 1, p. 1-33.

http://dx.doi.org/10.1201/9780203904039.ch1

PAUL, E. A.; HARRIS, D.; COLLINS, H. P.; SCHULTHESS, U.; ROBERTSON, G. P. Evolution of $\mathrm{CO}_{2}$ and soil carbon dynamics in biologically managed, row-crop agroecosystems. Applied Soil Ecology, Stillwater, v. 11, n. 1, p. 53-65, 1999. http://dx.doi.org/10.1016/S0929-1393(98)00130-9 
PFENNING, L.; EDUARDO, B. P.; CERRI, C. C. Os métodos de fumigação-incubação e fumigação-extração na estimativa da biomassa microbiana em solos da Amazônia. Revista Brasileira de Ciência do Solo, Campinas, v. 16, n. 1, p. 31-37, 1992.

REIS JUNIOR, F. B.; MENDES, I. C. Biomassa microbiana do solo. Planaltina: Embrapa Cerrados, 2007. 40 p. (Documentos, 205).

RIBEIRO, J. F.; WALTER, B. M. T. Fitofisionomias do bioma Cerrado. In: SANO, S. M.; ALMEIDA, S. P. (Ed.). Cerrado: ambiente e flora. Planaltina: EMBRAPA-CPAC, 1998. p. 89-166.

SANT'ANNA, S. A. C.; FERNANDES, M. F.; IVO, W. M. P. M.; COSTA, J. L. S. Evaluation of soil quality indicators in sugarcane management in sandy loam soil. Pedosphere, Beijing, v. 19, n. 3, p. 312-322, 2009. http://dx.doi.org/10.1016/S1002-0160(09)60122-3

SANTOS, V. B.; CASTILHOS, D. D.; CASTILHOS, R. M. V.; PAULETTO, E. A.; GOMES, A. S.; SILVA, D. G. Biomassa, atividade microbiana e teores de carbono e nitrogênio totais de um Planossolo sob diferentes sistemas de manejo. Revista Brasileira de Agrociência, Pelotas, v. 10, n. 3, p. 333-338, 2004.

SAS INSTITUTE Inc. SAS User's Guide: statistics. Version 9.1. Cary: SAS, 2003.

SHENG, H.; YANG, Y.; YANG, Z; CHEN, G.; XIE, J.; GUO, J.; ZOU, S. The dynamic response of soil respiration to land-use changes in subtropical China. Global Change Biology, Malden, v. 16, n. 3, p. 11071121, 2010. http://dx.doi.org/10.1111/j.1365-2486.2009.01988.x

SOUSA, R. F.; NASCIMENTO, J. L.; FERNANDES, E. P.; LEANDRO, W. M.; CAMPOS, A. B. Matéria orgânica e textura do solo em veredas conservadas e antropizadas no bioma Cerrado. Revista Brasileira de Engenharia Agrícola e Ambiental, Campina Grande, v. 15, n. 8, p. 861-866, 2011.

SPARLING, G. P. Ratio of microbial biomass carbon to soil organic carbon as a sensitive indicator of changes in soil organic matter. Australian Journal of Soil Research, Collingwood, v. 30, n. 2, p. 195-207, 1992. http://dx.doi.org/10.1071/SR9920195

STARK, C.; CONDRON, L. M.; STEWART, A.; DI, H.J.; O'CALLAGHAN, M. Effects of past and current crop management on soil microbial biomass and activity. Biology and Fertility of Soils, Firenzi, v. 43, n. 5, p. 531-540, 2007.

STOCKDALE, E. A.; BROOKES, P. C. Detection and quantification of the soil microbial biomass - impacts on the management of agricultural soils. Journal of Agricultural Science, Cambridge, v. 144, n. 4, p. 285-302, 2006. http://dx.doi.org/10.1017/S0021859606006228

TATE, R. L. III. Soil organic matter: biological and ecological effects. Malabar: Krieger Publishing Company, 1992. $291 \mathrm{p}$.

TÓTOLA, M. R.; CHAER, G. M. Microrganismos e processos microbiológicos como indicadores da qualidade do solo. In: ALVAREZ V., V. H.; SCHAEFER, C. E. G. R.; BARROS, N. F.; MELLO, J. W. V.; COSTA, L. M. (Ed.). Tópicos em Ciência do Solo. v. 2. Viçosa: Sociedade Brasileira de Ciência do Solo, 2002. p.195276.

TRUU, M.; JUHANSON, J.; TRUU, J. Microbial biomass, activity and community composition in constructed wetlands. Science of the Total Environment. Madison, v. 407, n. 13, p. 3958-3971, 2009.

TSAI, S. M.; BARAIBAR, A. V. L.; ROMANI, V. L. M. Efeito de fatores do solo. In: CARDOSO, E. J. B. N.; TSAI, S. M.; NEVES, M. C. P. (Coord.). Microbiologia do solo. Campinas: SBCS, 1992. cap. 5, p. 59-72. 
UDAWATTA, R. P.; KREMER, R. J.; GARRETT, H. E.; ANDERSON, S. H. Soil enzyme activities and physical properties in a watershed managed under agroforestry and row-crop systems. Agriculture, Ecosystems and Environment, Zürich, v. 131, n. 1-2, p. 98-104, 2009.

http://dx.doi.org/10.1016/j.agee.2008.06.001

VANCE, E. D.; BROOKES, P. C.; JENKINSON, D. S. An extraction method for measuring soil microbial biomass C. Soil Biology \& Biochemistry, Oxford, v. 19, n. 6, p.703-707, 1987.

http://dx.doi.org/10.1016/0038-0717(87)90052-6

WANG, K.-H.; MCSORLEY, R.; BOHLEN, P.; GATHUMBI, S. M. Cattle grazing increases microbial biomass and alters soil nematode communities in subtropical pastures. Soil Biology \& Biochemistry, Brisbane, v. 38, n. 7, p. 1956-1965, 2006. http://dx.doi.org/10.1016/j.soilbio.2005.12.019

WANG, W. J.; DALAL, R. C.; MOODY, P. W.; SMITH, C. J. Relationships of soil respiration to microbial biomass, substrate availability and clay content. Soil Biology \& Biochemistry, Brisbane, v. 35, n. 2, p. 273 284, 2003. http://dx.doi.org/10.1016/S0038-0717(02)00274-2

WARDLE, D. A. Metodologia para quantificação da biomassa microbiana do solo. In: HUNGRIA, M.; ARAUJO, R. S. (Ed.). Manual de métodos empregados em estudos de microbiologia agrícola. Brasília: EMBRAPA-SPI, 1994. cap. 21, p. 419-436. 